Article

\title{
Secondary Metabolites Profiling, Biological Activities and Computational Studies of Abutilon figarianum Webb (Malvaceae)
}

\author{
Hammad Saleem ${ }^{1,2}$, Muhammad Sarfraz ${ }^{3}$, Hafiz Muhammad Ahsan ${ }^{4}{ }^{(}$, , Umair Khurshid ${ }^{5}$, \\ Syed Asif Jahanzeb Kazmi ${ }^{4}$, Gokhan Zengin ${ }^{6}$ (D), Marcello Locatelli ${ }^{7}$ (D), Irshad Ahmad ${ }^{5}$, \\ Hassan H. Abdallah ${ }^{8}(\mathbb{D}$, Mohamad Fawzi Mahomoodally 9,10,*(D), Kannan RR Rengasamy 11,*(D) \\ and Nafees Ahemad ${ }^{1, *}$
}

1 School of Pharmacy, Monash University Malaysia, Jalan Lagoon Selatan, Bandar Sunway Selangor Darul Ehsan 47500, Malaysia; hammad.saleem@monash.edu

2 Institute of Pharmaceutical Sciences (IPS), University of Veterinary and Animal Sciences (UVAS), Lahore 54000, Pakistan; hammad.saleem@uvas.edu.pk

3 College of Pharmacy, Al Ain University, Al Ain 64141, UAE; muhammad.sarfraz@aau.ac.ae

4 Department of Pharmacology, CMH Institute of Medical Sciences, National University of Medical Sciences (NUMS), Bahawalpur 63100, Pakistan; ahsan.pharmacist@yahoo.com (H.M.A.); drsajk@yahoo.com (S.A.J.K.)

5 Department of Pharmacy, The Islamia University of Bahawalpur, Bahawalpur 63100, Pakistan; umairch.k@gmail.com (U.K.); drirshad.iub@gmail.com (I.A.)

6 Department of Biology, Faculty of Science, Selcuk University, Campus/Konya 42130, Turkey; gokhanzengin@selcuk.edu.tr

7 Department of Pharmacy, University 'G. d'Annunzio" of Chieti-Pescara, 66100 Chieti, Italy; m.locatelli@unich.it

8 Chemistry Department, College of Education, Salahaddin University, Erbil 44002, Iraq; hwchems@gmail.com 9 Institute of Research and Development, Duy Tan University, Da Nang 550000, Vietnam

10 Department of Health Sciences, Faculty of Science, University of Mauritius, Réduit 80837, Mauritius

11 Department of Bioresources and Food Science, Konkuk University, Seoul 05029, Korea

* Correspondence: mohamadfawzimahomoodally@duytan.edu.vn or f.mahomoodally@uom.ac.mu (M.F.M.); Rengasamy@iceir.net (K.R.R.); nafees.ahemad@monash.edu (N.A.)

Received: 6 February 2020; Accepted: 6 March 2020; Published: 13 March 2020

check for updates

\begin{abstract}
This research endeavors to inspect the chemical and biological profiling of methanol and dichloromethane (DCM) extracts prepared from Abutilon figarianum Webb. Total bioactive constituents and secondary metabolites were assessed via ultra-high performance liquid chromatography (UHPLC-MS). Biological effects were evaluated via antioxidant and enzymes inhibitory assays. The methanol extract was able to give the highest phenolic (51.92 mg GAE/g extract) and flavonoid (72.59 mg QE/g extract) contents and was found to contain 11 bioactive metabolites, including flavonoid, alkaloid, phenolic and fatty acid derivatives, as accessed by UHPLC-MS analysis. Similarly, the phytochemical profiling of the DCM extract tentatively identified the 12 different secondary metabolites, most of these were fatty acid derivatives. The methanol extract was most active in the radical scavenging, reducing power and total antioxidant power assays, while dichloromethane extract showed the highest metal chelating activity. For enzyme inhibition, the DCM extract showed the highest activity against cholinesterases, glucosidase and amylase, whereas methanol extract was most active against tyrosinase. Docking studies have supported the observed biological activity, where isobergapten showed higher activity against tyrosinase $(-7.63 \mathrm{kcal} / \mathrm{mol})$ with inhibition constant $(2.55 \mu \mathrm{M})$, as opposed to other enzymes. The observed antioxidant and inhibitory potentials of A. figarianum against the studied enzymes tend to endorse this plant as a prospective source of bioactive phytochemicals.
\end{abstract}


Keywords: phytochemical; docking; antioxidant; enzyme inhibition; bioactive molecules

\section{Introduction}

For hundreds of years, plants have been used as a potential source of medicines. People are dependent on plants for a panoply of uses such as food, wood, therapies, timber and non-timber forest products [1]. Plants are always considered as a potential source of biologically active drugs and have various traditional uses for the service of humanity since time immemorial [2]. A considerable amount of antioxidants, like polyphenols, is present in medicinal plants, which have a significant role in adsorption and neutralization of harmful free radicals. Antioxidants from herbal sources play a vital role in protection from various health disorders such as skin problems, diabetes mellitus, different types of cancers, Parkinson's (PD), Alzheimer's disease (AD) and oxidative stress [3]. Recently, the extracts and isolated compounds from herbal sources have been gaining more attention as a source of inhibitors for several enzymes involved in different clinical conditions [4]. Incidents of Alzheimer's disease, which can be linked to aging, is almost going to reach 81.1 million in 2040 [5]. Several factors are responsible for the gradual onset of $\mathrm{AD}$, such as a reduced level of acetylcholine in the brain. In light of the above, the remedial approach to manage the AD is slowing the key enzyme involved in the hydrolysis of neurotransmitters. Both $\mathrm{AChE}$ and $\mathrm{BChE}$ are responsible for cholinergic neurotransmission and are the key targets to cure Alzheimer's diseases [6]. Apart from this, other studies revealed that type II diabetes could increase the risk for the development of AD [7]. Type II diabetes, diagnosed with the increase in blood glucose level, is globally epidemic now. The major enzymes $\alpha$-amylase and $\alpha$-glucosidase, which carry out the absorption of carbohydrates, need to be inhibited, which is the crucial strategy for the treatment of hyperglycemia. Type II diabetes can also be linked with hyperpigmentation disorders of skin [8]. Tyrosinase, a Cu-containing enzyme, is the main remedial target for hyperpigmentation disorders like melisma [9]. A variety of plants are still unrevealed from their medicinal point of view, and biologically active compounds can be obtained from herbal sources. These biologically active compounds can cause improvement in the progress of new drugs for treatment/management of several pathologies.

Abutilon, is the vast genus from the family of Malvaceae that contains almost 150 annual or perennial herbs or small trees. It is usually found in the tropical and subtropical regions of Africa, America, Asia and Australia [10]. The genus Abutilon is of significant importance due to the presence of precious fibers obtained from different species of the same genus [11]. In general, the Abutilon species are responsible for the treatment of specific health problems, such as rheumatoid arthritis, and is used as a diuretic and demulcent as well due to the presence of a significant amount of mucilage [12,13]. Abutilon figarianum has been previously screened only for its antibacterial and antiviral activities $[14,15]$. Though, numerous species of the Abutilon genus are rarely known for its scientific benefits. In this current research, $A$. figarianum, the rarely studied plant from the Abutilon genus, was investigated for different enzymes implicated in the treatment of type II diabetes, AD and hyperpigmentation disorders of the skin. Antioxidant potential was also explored through six different in vitro biological assays. Similarly, chemical composition was established by determining total bioactive constituents and UHPLC-MS secondary metabolites profiling, followed by in silico docking studies.

\section{Materials and Methods}

\subsection{Plant Collection and Preparation}

Abutilon figarianum whole plant was harvested from Bahawalpur, Pakistan and authenticated by Dr. H. Waris, Taxonomist at Cholistan Institute of Desert Studies, The Islamia University of Bahawalpur. Besides this, a voucher specimen number (AF-A-04-15-150) was submitted to the herbarium (The Islamia University of Bahawalpur) for future reference. The plant material was dried in the shade 
for 15 days. After drying, the sample was ground into a fine powder and extracted by maceration (at room temperature) with both dichloromethane and methanol consecutively for $72 \mathrm{~h}$. The resulting extracts were evaporated to dryness at $40{ }^{\circ} \mathrm{C}$ using a rotary evaporator (R20).

\subsection{Phytochemical Composition}

The total phenolic (TPC) and flavonoid contents (TFC) were estimated as described previously and expressed as gallic acid equivalents (mg GAE/g extract) and quercetin equivalents (mg QE/g extract), respectively [16,17]. Moreover, RP-UHPLC-MS (Agilent 1290 Infinity LC system coupled to Agilent 6520 Accurate-Mass Q-TOF mass spectrometer with dual ESI source) was used for the determination of the secondary metabolite profile [18]. Data were processed with Agilent Mass Hunter Qualitative Analysis B.05.00. Identification of compounds was done from Search by METLIN database. The detailed protocols for total bioactive contents and UHPLC-MS instrumentation are provided as Supplementary material.

\subsection{Biological Assays}

The antioxidant activities were assayed using the method described previously [16]. The DPPH and ABTS radical scavenging ability, the ferric reducing antioxidant power (FRAP), and cupric reducing antioxidant power (CUPRAC), total antioxidant capacity through phosphomolybdenum assay and metal chelating ability were determined with the prepared extracts. All the antioxidant capabilities were expressed as Trolox equivalents (mg TE/g extract), while metal chelating power was expressed as mg EDTA/g.

In enzymatic assays, the inhibitory potential of extracts from plants against various enzymes such as cholinesterases, including acetylcholinesterase (AChE, E.C. 3.1.1.7) and butyrylcholinesterase (BChE, E.C. 3.1.1.8) (using Ellman's method), tyrosinase (E.C. 1.14.18.1), $\alpha$-amylase (E.C. 3.2.1.1) and $\alpha$-glucosidase (E.C. 3.2.1.20), were assessed as described previously [16,17]. In AChE and $\mathrm{BChE}$ inhibition study, galantamine was used as standard, and the results were expressed as $\mathrm{mg}$ of galantamine per gram of extract (GALAE/g), whereas, $\alpha$-amylase and $\alpha$-glucosidase inhibitory activity was recorded as millimoles (mmol) of acarbose equivalents per gram of extract (ACAE/g), and $\mathrm{mg}$ of kojic acid equivalent per gram of extract $(\mathrm{KAE} / \mathrm{g})$ was used to express tyrosinase inhibition. The detailed experimental procedures for these above mentioned biological assays are provided as Supplementary material.

\subsection{Docking Calculations}

In this study, isobergapten, 3-O-acetylhamayne and 6-hydroxyluteolin 5-rhamnoside were docked against the studied enzymes (AChE, BChE, tyrosinase, $\alpha$-amylase and $\alpha$-glucosidase). The 3D structures of these compounds were extracted from the online structure database, ZINC [19]. The configuration was viewed, optimized and the charge fixed using VegaZZ software [20] and the AM1 semi-empirical method. The structures of the studied enzymes were downloaded from Protein DataBank RCSB PDB. PDB code $4 E Y 6$ belongs to the structure of AChE in complex with galantamine, while PDB code 1P0P represents the structure of the $\mathrm{BChE}$ with butyrylthiocholine. PDB code $5 \mathrm{I} 38$ belongs to the crystal structure of the tyrosinase enzyme with kojic acid. Similarly, the structure of the enzymes $\alpha$-amylase and $\alpha$-glucosidase were extracted from the PDB codes 7TAA and 3W37, respectively, whereby both enzymes were crystallized with the acarbose inhibitor. Water and co-crystallized molecules were removed, and polar hydrogens were added to the structures before adding Kollman united atom charges to neutralize the proteins using Autodock4 software (Molinspiration Database). Docking the three compounds was performed using the Lamarckian genetic algorithm (LGA). The binding free energies of 250 conformations were produced for each inhibitor and control ligand, and the docked conformations were ranked based on the binding free energy $(\Delta G)$. Intermolecular interactions were identified for each enzyme-inhibitor complex using Discovery Studio 5.0 Visualizer. 


\subsection{Statistical Analysis}

All the experiments were executed in triplicates independently and given as mean \pm SD. The differences in the extracts were investigated by using student $t$-test $(p<0.05)$. The statistical value of $p<0.05$ was considered as significant. All the statistical analysis were done using SPSS v.17.0.

\section{Results and Discussion}

\subsection{Phytochemical Composition}

In this study, DCM and methanol solvents were used for the preparation of extracts such solvents have low boiling points and generally easier to concentrate. Medium-polarity solvents are used to extract compounds of intermediate polarity (e.g., some alkaloids, flavonoids), while more polar ones like methanol are used for more polar compounds (e.g., flavonoid glycosides, tannins, some alkaloids) [21]. Flavonoids and phenolic compounds are significant and vital classes of phytochemicals and panoply of such bioactive compounds are present in tissues of plants. At the current time, several scientific studies have explored that phenolic compounds are capable of producing a variety of biological effects [22]. Therefore, defining the phenolic content in a plant sample is a key step in the determination of its therapeutic potential. In the present research, the total amount of phenolic content of both the extracts were established by a well-known Folin-Ciocalteu assay and the results were expressed as $\mathrm{mg}$ GAE/g extract in Table 1.

Table 1. Total bioactive contents in A. figarianum extracts.

\begin{tabular}{ccc}
\hline Extracts & Total Phenolic Content (mg GAE/g) & Total Flavonoid Content (mg QE/g) \\
\hline AF-M & $51.92 \pm 0.80^{\mathrm{a}}$ & $72.59 \pm 0.47^{\mathrm{a}}$ \\
AF-D & $18.71 \pm 0.43^{\mathrm{b}}$ & $40.43 \pm 0.32^{\mathrm{b}}$ \\
\hline
\end{tabular}

AF-M: A. figarianum methanol extract; AF-D: A. figarianum DCM extract. GAE: Gallic acid equivalent; QE: Quercetin equivalent. All values expressed are means \pm S.D. of three parallel measurements. Different letters indicate significant differences in the tested extracts $(p<0.05)$.

According to the results, it was seen that the methanol (51.92 mg GAE/g extract) extract contained more phenolic content than DCM (18.71 mg GAE/g extract). Similarly, total flavonoid content was determined (by utilizing aluminum chloride method) in comparison with quercetin standard and the results were expressed as $\mathrm{mg} \mathrm{QE} / \mathrm{g}$ extract. The same pattern for TPC was noted, and the methanol (72.59 mg QE/g extract) extract revealed the more considerable amount of flavonoids in comparison with DCM (40.43 mg QE/g extract) extract. Overall, it was observed that the plant contains a higher amount of flavonoids and these results show similarity with the earlier study conducted by Srividya et al. (2012), who also found the highest flavonoid content as compared to phenolic in different extracts of $A$. indicum [23].

Similarly, the secondary metabolite profiling of the methanolic extract of $A$. figarianum through UHPLC-MS analysis as indicated in Table 2, discovered the tentative occurrence of 11 different secondary metabolites and its total ion chromatogram is shown in Figure 1A. 
Table 2. UHPLC-MS analysis of methanol extract of $A$. figarianum.

\begin{tabular}{|c|c|c|c|c|c|c|c|}
\hline S.no & RT (min) & B. Peak $(m / z)$ & Tentative Compound Identification & Comp. Class & Mol. Formula & Mol. Mass & DB Diff (ppm) \\
\hline 1 & 2.65 & 215.0411 & Isobergapten & Coumarin & $\mathrm{C}_{12} \mathrm{H}_{8} \mathrm{O}_{4}$ & 216.0411 & 5.49 \\
\hline 2 & 2.67 & 165.0488 & 1-Methylxanthine & Alkaloid & $\mathrm{C}_{6} \mathrm{H}_{6} \mathrm{~N}_{4} \mathrm{O}_{2}$ & 166.0488 & 1.52 \\
\hline 3 & 12.24 & 461.0807 & 5,6,7,2'-Tetrahydroxyflavone 7-glucuronide & Flavonoid & $\mathrm{C}_{21} \mathrm{H}_{18} \mathrm{O}_{2}$ & 462.0807 & -1.94 \\
\hline 4 & 12.57 & 173.0895 & Suberic acid & Organic Acid & $\mathrm{C}_{8} \mathrm{H}_{14} \mathrm{O}_{4}$ & 174.0895 & -1.54 \\
\hline 5 & 12.59 & 447.1011 & 6-Hydroxyluteolin 5-rhamnoside & Flavonoid & $\mathrm{C}_{21} \mathrm{H}_{20} \mathrm{O}_{11}$ & 448.1011 & -1.23 \\
\hline 6 & 12.774 & 328.127 & 3-O-Acetylhamayne & Alkaloid & $\mathrm{C}_{18} \mathrm{H}_{19} \mathrm{NO}_{5}$ & 329.127 & -1.96 \\
\hline 7 & 12.776 & 445.0851 & 5,7,2'-Trihydroxyflavone 7-glucuronide & Flavonoid & $\mathrm{C}_{21} \mathrm{H}_{18} \mathrm{O}_{11}$ & 446.0851 & -0.44 \\
\hline 8 & 13.23 & 521.1375 & Chrysosplenoside D & Flavonoid & $\mathrm{C}_{24} \mathrm{H}_{26} \mathrm{O}_{13}$ & 522.1375 & -0.3 \\
\hline 9 & 13.79 & 593.1385 & Kaempferol 3-(2"'-(Z)-p-coumaroylglucoside) & Flavonoid & $\mathrm{C}_{30} \mathrm{H}_{26} \mathrm{O}_{13}$ & 594.1385 & -1.91 \\
\hline 10 & 15.15 & 329.241 & 5,8,12-trihydroxy-9-octadecenoic acid & Fatty acid & $\mathrm{C}_{18} \mathrm{H}_{34} \mathrm{O}_{5}$ & 330.241 & -1.06 \\
\hline 11 & 17.70 & 293.1826 & Gingerol & Phenol & $\mathrm{C}_{17} \mathrm{H}_{26} \mathrm{O}_{4}$ & 294.1826 & 1.7 \\
\hline
\end{tabular}

RT—retention time; B. peak—base peak; DB-database. 


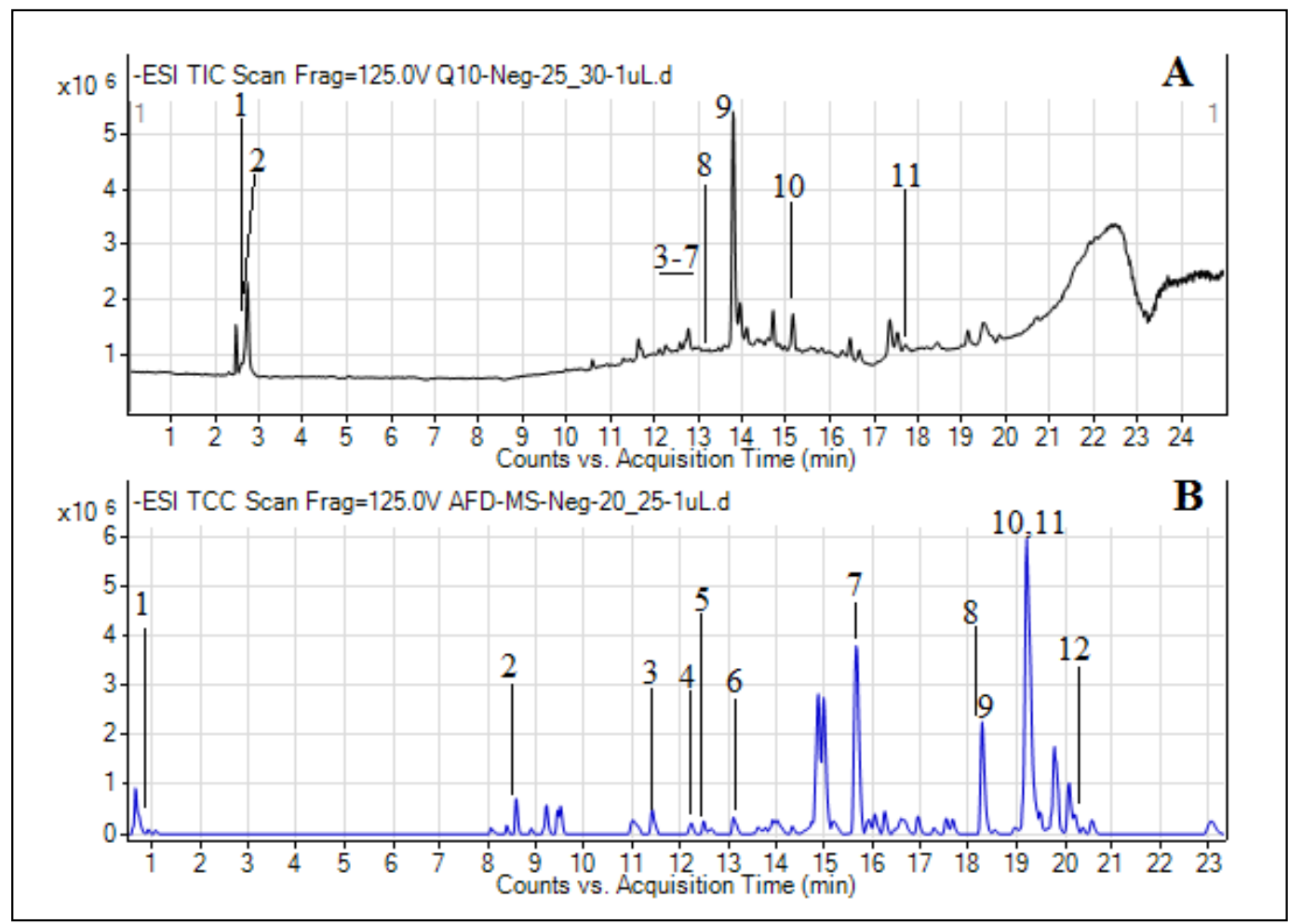

Figure 1. Total ion chromatograms (TICs) of methanol (A) and dichloromethane (DCM) (B) extracts of A. figarianum.

Most of these were belonging to the flavonoids class of compounds including 5, 6, and 7, 2'-tetrahydroxyflavone 7-glucuronide, 6-hydroxyluteolin 5-rhamnoside, 5, 7, 2' -trihydroxyflavone 7-glucuronide, chrysosplenoside D and kaempferol 3-(2"-(Z)-p-coumaroylglucoside). Moreover, two alkaloids (1-methylxanthine and 3-O-Acetylhamayne), one phenolic (gingerol) and one fatty acid (5, 8, 12-trihydroxy-9-octadecenoic acid) were also identified. Similarly, the DCM extract was made soluble in methanol solvent and was run for UHPLC-MS profiling, and the results are presented in Table 3. The TIC for DCM extract can be seen in Figure 1B. Most of the secondary metabolites which were tentatively identified by the database in this extract were fatty acid, organic acids and phenol derivatives. The fatty acids identified were 5,8,12-trihydroxy-9-octadecenoic acid, 12-oxo-10Z-octadecenoic acid, 9Z,12Z,15E-octadecatrienoic acid, 1-Linoleoyl glycerol and 6E,9E-octadecadienoic acid. Similarly, citric acid and suberic acid were the two organic acids identified in this extract. Likewise, two phenol derivatives named gingerol and methyl gingerol were also identified by the database. Moreover, one lactone derivative (dihydroalbocycline), isoprenylated flavonoid derivative (Sanggenon G) and glucopyranoside derivative (cis-3-Hexenyl b-primeveroside) were also tentatively identified. The presence of phenolic, flavonoid, alkaloid, fatty acid and coumarin derivatives in both the methanol and DCM extracts of $A$. figarianum are in accordance with some of the previous studies conducted on different species of this genus which had also reported the presence of these secondary metabolites classes in this species $[15,24,25]$. As far as the literature review concerns, this is the first and foremost study on UHPLC-MS secondary metabolites composition of methanol extract of A. figarianum. 
Table 3. UHPLC-MS analysis of DCM extract of A. figarianum.

\begin{tabular}{|c|c|c|c|c|c|c|c|}
\hline S.no & RT (min) & B. Peak $(m / z)$ & Tentative Compound Identification & Comp. Class & Mol. Formula & Mol. Mass & DB Diff (ppm) \\
\hline 1 & 0.913 & 191.0277 & Citric acid & Organic Acid & $\mathrm{C}_{6} \mathrm{H}_{8} \mathrm{O}_{7}$ & 192.0277 & -3.68 \\
\hline 2 & 8.578 & 173.0892 & Suberic acid & Organic Acid & $\mathrm{C}_{8} \mathrm{H}_{14} \mathrm{O}_{4}$ & 174.0892 & 0.01 \\
\hline 3 & 11.414 & 3298.2399 & 5,8,12-trihydroxy-9-octadecenoic acid & Fatty acid & $\mathrm{C}_{18} \mathrm{H}_{34} \mathrm{O}_{5}$ & 330.2399 & 2.32 \\
\hline 4 & 12.222 & 309.2156 & Dihydroalbocycline & Lactone & $\mathrm{C}_{18} \mathrm{H}_{30} \mathrm{O}_{4}$ & 310.2156 & -3.96 \\
\hline 5 & 12.482 & 307.1996 & Methylgingerol & Phenol & $\mathrm{C}_{18} \mathrm{H}_{28} \mathrm{O} 4$ & 308.1996 & -2.78 \\
\hline 6 & 13.106 & 293.184 & Gingerol & Phenol & $\mathrm{C}_{17} \mathrm{H}_{26} \mathrm{O}_{4}$ & 294.184 & -3.08 \\
\hline 7 & 15.663 & 295.2357 & 12-oxo-10Z-octadecenoic acid & Fatty acid & $\mathrm{C}_{18} \mathrm{H}_{32} \mathrm{O}_{3}$ & 296.2357 & -1.91 \\
\hline 8 & 18.277 & 277.2242 & 9Z,12Z,15E-octadecatrienoic acid & Fatty acid & $\mathrm{C}_{18} \mathrm{H}_{30} \mathrm{O}_{2}$ & 278.2242 & 1.2 \\
\hline 9 & 18.309 & 353.2781 & 1-Linoleoyl Glycerol & Fatty acid & $\mathrm{C}_{21} \mathrm{H}_{38} \mathrm{O}_{4}$ & 354.2781 & -2.99 \\
\hline 10 & 19.211 & 693.2344 & Sanggenon G & Isoprenylated flavonoid & $\mathrm{C}_{40} \mathrm{H}_{38} \mathrm{O}_{11}$ & 694.2344 & 10.12 \\
\hline 11 & 19.212 & 279.2416 & 6E,9E-octadecadienoic acid & Fatty acid & $\mathrm{C}_{18} \mathrm{H}_{32} \mathrm{O}_{2}$ & 280.2416 & -4.92 \\
\hline 12 & 20.384 & 393.1834 & cis-3-Hexenyl b-primeveroside & Glucopyranoside derivative & $\mathrm{C}_{17} \mathrm{H}_{30} \mathrm{O}_{10}$ & 394.1834 & 1.39 \\
\hline
\end{tabular}

RT—retention time; B. peak—base peak; DB—database 


\subsection{Antioxidant Potential}

Antioxidant potential of $A$. figarianum was identified by using a series of assays which includes free radical scavenging (ABTS and DPPH), reducing power (CUPRAC and FRAP), phosphomolybdenum and ferrous ion chelating assays. As presented in Table 4, the DPPH scavenging potential revealed the maximum value for methanol extract (66.64 $\mathrm{mg} \mathrm{TE} / \mathrm{g}$ extract).

Table 4. Antioxidant properties of $A$. figarianum extracts.

\begin{tabular}{lcccccc}
\hline \multirow{2}{*}{ Extracts } & \multicolumn{2}{c}{ Radical Scavenging Activity } & \multicolumn{2}{c}{ Reducing Power } & $\begin{array}{c}\text { Total Antioxidant } \\
\text { Capacity }\end{array}$ & Ferrous Chelating \\
\cline { 2 - 6 } & $\begin{array}{c}\text { DPPH } \\
\text { (mgTE/g Extract) }\end{array}$ & $\begin{array}{c}\text { ABTS } \\
(\mathbf{m g T E} / \mathbf{g} \text { Extract) }\end{array}$ & $\begin{array}{c}\text { FRAP } \\
(\mathbf{m g T E} / \mathbf{g} \text { Extract)) }\end{array}$ & $\begin{array}{c}\text { CUPRAC } \\
(\mathbf{m g T E} / \mathbf{g} \text { Extract) }\end{array}$ & $\begin{array}{c}\text { Phosphomolybdenum } \\
\text { (mgTE/g Extract) }\end{array}$ & $\begin{array}{c}\text { Metal Chelating } \\
\text { (mgEDTAE/g Extract) }\end{array}$ \\
\hline AF-M & $66.64 \pm 1.42^{\mathrm{a}}$ & $120.92 \pm 1.99^{\mathrm{a}}$ & $123.16 \pm 5.73^{\mathrm{a}}$ & $204.26 \pm 0.34^{\mathrm{a}}$ & $2.51 \pm 0.13^{\mathrm{a}}$ & $40.15 \pm 0.34^{\mathrm{b}}$ \\
AF-D & $4.83 \pm 0.94^{\mathrm{b}}$ & $13.87 \pm 1.32^{\mathrm{b}}$ & $30.63 \pm 0.94^{\mathrm{b}}$ & $77.60 \pm 4.50^{\mathrm{b}}$ & $1.39 \pm 0.16^{\mathrm{b}}$ & $51.57 \pm 0.25^{\mathrm{a}}$ \\
\hline TE: Trolox equivalent; EDTAE: EDTA equivalent. All values expressed are means \pm S.D. of three parallel \\
measurements. Different letters indicate significant differences in the tested extracts $(p<0.05)$.
\end{tabular}

Same as DPPH assay, the ABTS scavenging activity followed the same pattern and methanol extract showed highest ABTS activity (120.92 mg TE/g extract), and methanol extract showed a similar pattern with total flavonoid and phenolic content. The reducing capability of both extracts was accessed through FRAP and CUPRAC assays, as shown in Table 3. The methanol extract was found to be very potent in both the assays (FRAP: 123.16; CUPRAC: $204.26 \mathrm{mg}$ TE/g extract) as compared to DCM extract (FRAP: 30.63 ; CUPRAC: $77.60 \mathrm{mg}$ TE/g extract). This information is not unexpected as DCM extract displayed less phenolic content. One or more than one hydroxyl group are attached to the benzene ring, and this structural quality is responsible for its antioxidant potential [26]. Amazingly, the previous studies revealed that higher DPPH scavenging activity is related to the presence of high phenolic content $[9,27,28]$.

Phosphomolybdenum assay was used to establish the total antioxidant effect of the A. figarianum extracts and the methanol extract revealed the highest activity (2.51 $\mathrm{mg}$ TE/g extract) (Table 4). The current outcomes are in agreement with the total phenolic content. Furthermore, the ferrous ion chelating capacities of the extracts were determined, which revealed that DCM extract has the highest metal chelating ability (40.15 mg EDTAE/g extract) (Table 3). In comparison with other antioxidant assays, the current results may be due to the occurrence of non-phenolic chelators and synergetic and/or antagonistic action of phytochemicals $[29,30]$. Similarly, certain studies explained that there is no correlation some between phenolic contents and this activity [31]. Antioxidant potential of A. figarianum using six different assays was determined, which indicates that this plant has a potent antioxidant capacity. Though, the choice of method and the solvent used for extraction plays a vital role in the determination of the antioxidant potential of the prepared extracts. In similar studies, it was found that the antioxidant potential of extracts depends upon the total phenolic and flavonoid contents [22,32], that is in accordance with our study. Thus, in this study, the higher amount of total phenolic and flavonoid content may be responsible for the potent antioxidant potential.

\subsection{Enzyme Assays}

AChE plays an essential role in the breakdown of nervous impulse during transmission at the cholinergic synapse, where the hydrolysis of acetylcholine occurs [33]. This is the first time that AChE inhibitory effect of $A$. figarianum was studied and the results obtained can be seen in Table 5 .

Both methanol and DCM extracts showed significant inhibition against AChE with values of 3.33 and $4.50 \mathrm{mg}$ of GALAE/g extract, respectively. For BChE inhibitory studies, DCM extract was most active (4.55 mg GALAE/g extract), whereas methanol extract expressed least inhibitory effect (1.67 mg GALAE/g extract). On the whole, DCM extract was comparatively most active against both cholinesterases as compared to methanol extract. The higher inhibition expressed by DCM extracts can be associated with the presence of non-phenolic compounds same as alkaloids, which are reported earlier cholinesterase inhibition [34,35]. Before, the methanol extract of $A$. indicum was 
reported for AChE percentage inhibition of $30.66 \pm 1.06(0.1 \mathrm{mg} / \mathrm{mL})[36,37]$. Similarly, another study by Parmar et al. (2017) reported that the memory retention and cognitive improvement capacity of methanol extract of $A$. indicum was evaluated against the Alzheimer's disease induced by aluminum chloride in rats, and also expressed considerable decrease in transfer latency in all learning and memory models, which indicates the effectiveness in improving the cognitive impairment caused by aluminum chloride and, hence, improving memory [38].

Table 5. Enzyme inhibitory activities of A. figarianum extracts.

\begin{tabular}{cccccc}
\hline Extracts & $\begin{array}{c}\text { AChE (mg } \\
\text { GALAE/g } \\
\text { Extract) }\end{array}$ & $\begin{array}{c}\text { BChE (mg } \\
\text { GALAE/g } \\
\text { Extract) }\end{array}$ & $\begin{array}{c}\text { Tyrosinase } \\
\text { (mg KAE/g } \\
\text { Extract) }\end{array}$ & $\begin{array}{c}\text { Glucosidase } \\
\text { (mmol } \\
\text { ACAE/g } \\
\text { Extract) }\end{array}$ & $\begin{array}{c}\text { Amylase } \\
\text { (mmol } \\
\text { ACAE/g } \\
\text { Extract) }\end{array}$ \\
\hline AF-M & $3.33 \pm 0.08^{\mathrm{b}}$ & $1.67 \pm 0.08^{\mathrm{b}}$ & $129.01 \pm 0.97^{\mathrm{a}}$ & $0.60 \pm 0.03^{\mathrm{a}}$ & $1.72 \pm 0.05^{\mathrm{a}}$ \\
AF-D & $4.50 \pm 0.59^{\mathrm{a}}$ & $4.55 \pm 0.26^{\mathrm{a}}$ & $112.89 \pm 2.16^{\mathrm{b}}$ & $0.65 \pm 0.02^{\mathrm{a}}$ & $1.88 \pm 0.04^{\mathrm{a}}$ \\
\hline
\end{tabular}

GALAE-galantamine equivalent; KAE—-kojic acid equivalent; ACAE—acarbose equivalent; all values expressed are means \pm S.D. of three parallel measurements. Different letters indicate significant differences in the tested extracts $(p<0.05)$.

$\alpha$-Amylase and $\alpha$-glucosidase are key enzymes responsible for the hydrolysis of carbohydrates during digestion. Inhibitors of $\alpha$-glucosidase are from that category of antidiabetic drugs which decreases the postprandial hyperglycemia by inhibiting the enzymes for carbohydrate hydrolysis, thus delays the absorption of glucose in blood [39]. Due to the hazardous side effects of the used drugs, like acarbose, and also drug resistance, scientists are motivated to discover new herbal sources to search novel $\alpha$-amylase and $\alpha$-glucosidase inhibitors [22]. In both $\alpha$-glucosidase and $\alpha$-amylase inhibitory studies, the DCM extracts showed the highest inhibition, with values of 0.65 and $1.88 \mathrm{mmol}$ ACAE/g extract, respectively. Similarly, the methanol extract also showed significant amylase inhibition (1.72 mmol ACAE/g extract), but least active for glucosidase $(0.60 \mathrm{mmol}$ ACAE/g extract). This result might be explained by the supposition that the DCM extracts of $A$. figarianum may have those particular compounds which are responsible for inhibition. Following our findings, some earlier reports indicate that total phenolic content and anti-diabetic effect cannot be correlated [40-42]. A previous study has reported the dose-dependent percentage inhibition by $A$. indicum leaves extract for $\alpha$-amylase inhibition $(7.12 \%-41.31 \%)$ and $\alpha$-glucosidase inhibition $(8.01 \%-36.13 \%)$ [43].

The major enzyme responsible for several skin problems, such as hyperpigmentation and Alzheimer's disease, is tyrosinase, so it is necessary to inhibit its activity for the treatment of previously mentioned diseases [22]. The inhibitory effect of tyrosinase by A. figarianum extracts are presented in Table 4 and both the extracts showed considerable tyrosinase inhibition, with values of $129.01 \mathrm{mg}$ $\mathrm{KAE} / \mathrm{g}$ extract for methanol extract and $112.89 \mathrm{mg} \mathrm{KAE} / \mathrm{g}$ extract for DCM. The observed activity of methanol extract of $A$. figarianum can be related to the higher concentration of phenolic compounds, and this finding was in agreement with previous studies done by numerous scientists that there is a very strong association between total phenolic content and tyrosinase inhibition $[44,45]$.

\subsection{Docking Results}

To correlate the experimental findings and elucidate the binding affinity of three selected dominant compounds with $\mathrm{AChE}, \mathrm{BChE}$, tyrosinase, $\alpha$-amylase and $\alpha$-glucosidase enzymes, docking calculations were executed. Before the docking of the proposed inhibitors, control compounds were docked first to confirm the active site and evaluate the docking procedure. The docking results are mentioned in Table 6, in which the binding free energies are listed with the inhibition constant and the formed intermolecular interactions with the catalytic residues at the active site of the enzymes. Figure 2 shows that the docked compounds are at the active site of the enzyme. Isobergapten showed similar inhibition activity with the five enzymes; however, it showed higher activity against tyrosinase enzyme $(-7.63 \mathrm{kcal} / \mathrm{mol})$ with inhibition constant $(2.55 \mu \mathrm{M})$ in comparison with the rest of the studied enzymes. 
Among the different interactions of this inhibitor with the active site, pi-pi interactions are dominant, as shown in Figure 2. In contrast, 6-hydroxyluteolin 5-rhamnoside showed a higher affinity with $\mathrm{AChE}$, in comparison with the rest of the enzymes with binding free energy $(-11.26 \mathrm{kcal} / \mathrm{mol})$ and estimated inhibition constant $(5.61 \mathrm{nM})$. This inhibition activity is mainly attributed to the high number of hydrogen bonds formed with the residues Glu 202, Tyr 337, Tyr 124, Ser 293 and Arg 296 at the active site, as shown in Figure 2. 3-O-acetylhamayne has shown similar high-binding energy with AChE enzyme, with binding free energy $(-9.38 \mathrm{kcal} / \mathrm{mol})$ and projected inhibition constant $(133.91 \mathrm{nM})$. Besides the hydrogen bonds with the amino acids Tyr 124 and Tyr 133, pi-pi interactions are the dominant interactions between 3-O-acetylhamayne and the active site of AChE, as shown in Figure 2.
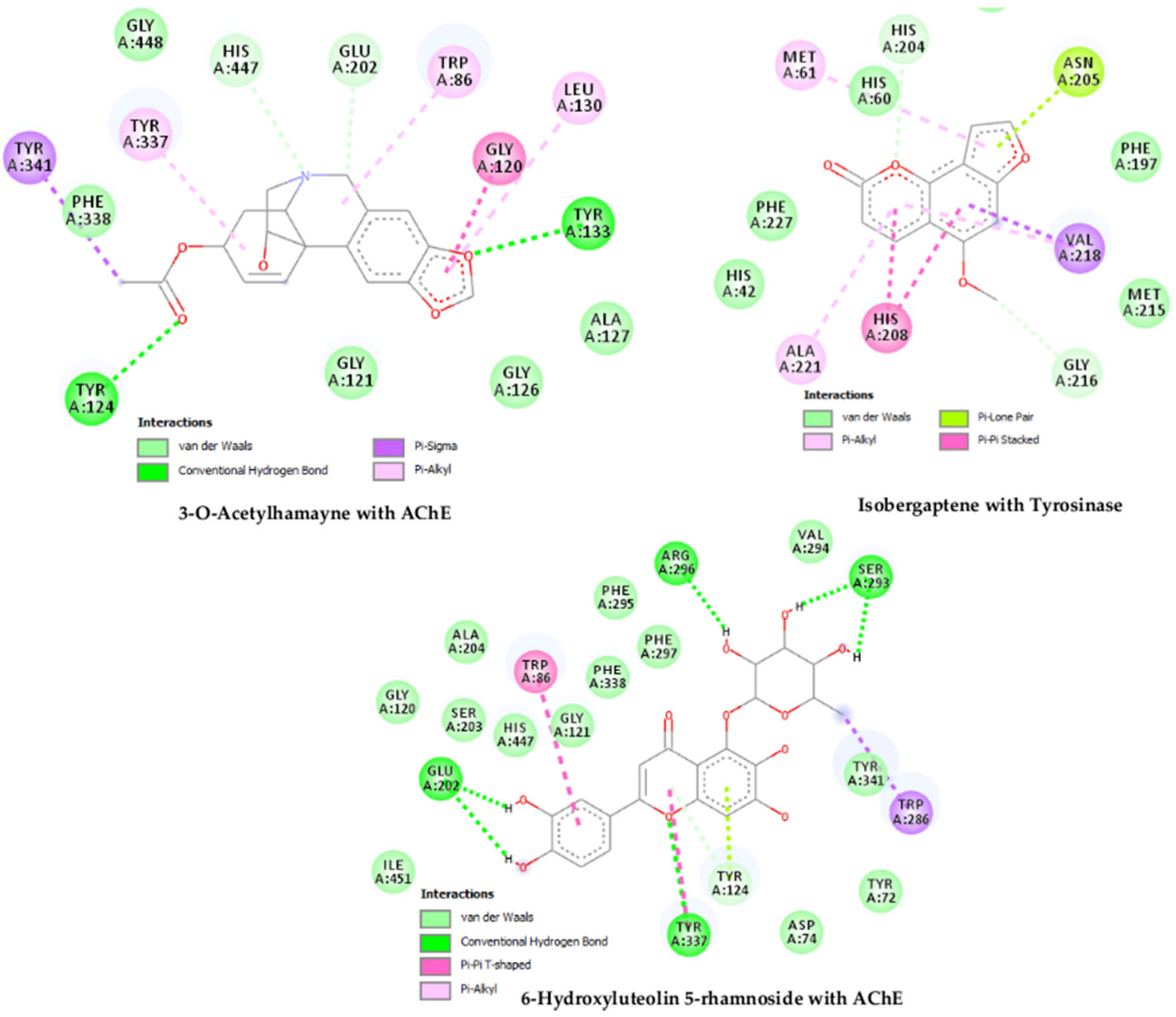

Figure 2. Docked compounds at the active site of the enzyme and their interactions. 
Table 6. Binding energy ( $\mathrm{kcal} / \mathrm{mol})$, inhibition constant $\mathrm{K}_{\mathrm{i}}$, interaction sites between isobergapten, 6-hydroxyluteolin 5-rhamnoside and 3-O-acetylhamayne against studied enzymes.

\begin{tabular}{|c|c|c|}
\hline & $\begin{array}{l}\text { Binding Energy/Inhibition } \\
\text { Constant } K_{i}\end{array}$ & Interaction Site \\
\hline \multicolumn{3}{|l|}{ Isobergapten } \\
\hline $\mathrm{AChE}$ & $-6.99(7.50 \mu \mathrm{M})$ & Ala 127(HB), Tyr 133(HB), Trp 86 \\
\hline BChE & $-6.52(16.53 \mu \mathrm{M})$ & Tyr 440(HB), Trp 82(HB), His 438, Tyr 332, Ala 328, Phe 329 \\
\hline Tyrosinase & $-7.63(2.55 \mu \mathrm{M})$ & Met 61, His 60, Asn 205, Val 218, Gly 216, His 208, Ala 221 \\
\hline$\alpha$-amylase & $-6.30(23.92 \mu \mathrm{M})$ & Lys 209(HB), Leu 232, Glu 230, Val 231, His 210, Tyr 155 \\
\hline$\alpha$-glucosidase & $-7.33(4.27 \mu \mathrm{M})$ & Arg 552(HB), Met 470, Phe 601, Asp 469, Ile 358 \\
\hline \multicolumn{3}{|c|}{ 6-Hydroxyluteolin 5-rhamnoside } \\
\hline $\mathrm{AChE}$ & $-11.26(5.61 \mathrm{nM})$ & $\begin{array}{l}\text { Glu 202(HB), Trp 86, Tyr 337(HB), Tyr 124(HB), Trp 286, } \\
\text { Ser 293(HB), Arg 296(HB) }\end{array}$ \\
\hline BChE & $-5.90(47.49 \mu \mathrm{M})$ & $\begin{array}{l}\text { Ile 69(HB), Asp 70(HB), Gly 116(HB), Thr 120, Trp 82, } \\
\text { Glu 197(HB), His 438(HB) }\end{array}$ \\
\hline Tyrosinase & $-4.77(318.76 \mu \mathrm{M})$ & Gly 200(HB), Arg 209, Val 218, His 208, Ala 221, His 60(HB) \\
\hline$\alpha$-amylase & $-4.87(268.16 \mu \mathrm{M})$ & $\begin{array}{l}\text { Leu 232(HB), Lys 209, His 210, Leu 166, Leu 173, His } \\
\text { 122(HB), Tyr 82, Trp } 83\end{array}$ \\
\hline$\alpha$-glucosidase & $-8.04(1.28 \mu \mathrm{M})$ & $\begin{array}{l}\text { Ala 234(HB), Asp 568, Arg 552(HB), Met 470, Trp 432(HB), } \\
\text { Asp 469(HB), Asp 357(HB), Trp 565 }\end{array}$ \\
\hline \multicolumn{3}{|c|}{ 3-O-Acetylhamayne } \\
\hline $\mathrm{AChE}$ & $-9.38(133.91 \mathrm{nM})$ & $\begin{array}{l}\text { Tyr 124(HB), Tyr 341, Tyr 337, His 447, Glu 202, Trp 86, } \\
\text { Gly } 120 \text {, Leu } 130 \text {, Tyr } 133(\mathrm{HB})\end{array}$ \\
\hline $\mathrm{BChE}$ & $-8.84(329.84 \mathrm{nM})$ & Thr 122(HB), His 438, Ala 328, Trp 82 \\
\hline Tyrosinase & $-7.13(5.96 \mu \mathrm{M})$ & $\begin{array}{l}\text { Asn } 205 \text { (HB), Phe 197, Arg 209, Gly 216, Val 217, Val 218, } \\
\text { His 208, His 60, His 204, Ala } 221\end{array}$ \\
\hline$\alpha$-amylase & $-6.37(21.52 \mu \mathrm{M})$ & Asp 206(HB), Leu 173, Leu 166, Glu 230, Leu 232, Asp 297 \\
\hline$\alpha$-glucosidase & $-6.36(21.87 \mu \mathrm{M})$ & Asp 568(HB), Trp 432, Phe 476, Trp 329, Phe 601 \\
\hline
\end{tabular}

$(\mathrm{HB})^{*}$-hydrogen bond.

\section{Conclusions}

The current work can be considered as the extensive and detailed work focusing on the phytochemical characterization, antioxidant and enzyme inhibition effects of A. figarianum. The methanol extract was observed to be rich in bioactive compounds, which can be correlated to the observed higher antioxidant potential. The plant was found to contain well-known flavonoids, alkaloids, fatty acid and phenolic compounds. The biological activity was confirmed by the docking calculations in which the binding free energies were calculated, and the interactions with the active site are elucidated. The plant extracts expressed the significant results for the treatment of diabetes, Alzheimer's disease and skin hyperpigmentation disorders.

Supplementary Materials: The following are available online at http://www.mdpi.com/2227-9717/8/3/336/s1. The detailed protocols for total bioactive contents, UHPLC-MS instrumentation, and biological (antioxidant and enzyme inhibition) assays are provided as Supplementary material.

Author Contributions: Conceptualization, I.A., and M.S.; Formal analysis, H.S., G.Z., M.L., M.F.M. and K.R.R.; Methodology, H.S., G.Z., M.L. and H.H.A.; Software, G.Z. and H.H.A.; Docking studies: H.H.A; Supervision, S.A.J.K., I.A. and N.A.; Writing—original draft, H.S., H.M.A., M.F.M. and U.K.; Writing-review and editing, K.R.R. All authors have read and agreed to the published version of the manuscript.

Funding: This research received no external funding.

Conflicts of Interest: Authors declare no conflicts of interest.

\section{References}

1. Jain, A.; Katewa, S.; Galav, P.; Sharma, P. Medicinal plant diversity of Sitamata wildlife sanctuary, Rajasthan, India. J. Ethnopharmacol. 2005, 102, 143-157. [CrossRef] [PubMed]

2. Kaushik, P.; Kaushik, D.; Khokra, S.; Chaudhary, B. Abutilon indicum (Atibala): Ethno-botany, phytochemistry and pharmacology-A review. Int. J. Pharm. Clin. Res. 2009, 1, 4-9. 
3. Bahadori, M.B.; Asghari, B.; Dinparast, L.; Zengin, G.; Sarikurkcu, C.; Abbas-Mohammadi, M.; Bahadori, S. Salvia nemorosa L. A novel source of bioactive agents with functional connections. LWT-Food Sci. Technol. 2017, 75, 42-50. [CrossRef]

4. Zengin, G.; Uysal, A.; Diuzheva, A.; Gunes, E.; Jekő, J.; Cziáky, Z.; Picot-Allain, C.M.N.; Mahomoodally, M.F. Characterization of phytochemical components of Ferula halophila extracts using HPLC-MS/MS and their pharmacological potentials: A multi-functional insight. J. Pharm. Biomed. Anal. 2018, 160,374-382. [CrossRef] [PubMed]

5. Dhouafli, Z.; Rigacci, S.; Leri, M.; Bucciantini, M.; Mahjoub, B.; Tounsi, M.S.; Wannes, W.A.; Stefani, M.; Hayouni, E.A. Screening for amyloid- $\beta$ aggregation inhibitor and neuronal toxicity of eight Tunisian medicinal plants. Ind. Crops Prod. 2018, 111, 823-833. [CrossRef]

6. Li, Q.; Tu, Y.; Zhu, C.; Luo, W.; Huang, W.; Liu, W.; Li, Y. Cholinesterase, $\beta$-amyloid aggregation inhibitory and antioxidant capacities of Chinese medicinal plants. Ind. Crops Prod. 2017, 108, 512-519. [CrossRef]

7. Li, W.; Risacher, S.L.; Gao, S.; Boehm II, S.L.; Elmendorf, J.S.; Saykin, A.J.; Initiative, A.s.D.N. Type 2 diabetes mellitus and cerebrospinal fluid Alzheimer's disease biomarker amyloid $\beta 1-42$ in Alzheimer's Disease Neuroimaging Initiative participants. Alzheimer Dement. Diagn. Assess. Dis. Monit. 2018, 10, 94-98. [CrossRef]

8. Mendes, A.L.; Miot, H.A.; Haddad Junior, V. Diabetes mellitus and the skin. An. Bras. Dermatol. 2017, 92, 8-20. [CrossRef]

9. Zengin, G.; Bulut, G.; Mollica, A.; Picot-Allain, C.M.N.; Mahomoodally, M.F. In vitro and in silico evaluation of Centaurea saligna (K. Koch) Wagenitz-An endemic folk medicinal plant. Comput. Biol. Chem. 2018, 73, 120-126. [CrossRef]

10. Arbat, A.A. Pharmacognostic studies of stem of Abutilon pannosum (Forst F.). Biosci. Discov. 2012, 3, 317-320.

11. Gomaa, A.; Samy, M.N.; Desoukey, S.Y.; Kamel, M.S. Pharmacognostical studies of leaf, stem, root and flower of Abutilon hirtum (Lam.) Sweet. Int. J. Pharmacogn. Phytochem. Res. 2016, 8, 199-216.

12. Ali, B.; Ibrahim, M.; Hussain, I.; Hussain, N.; Imran, M.; Nawaz, H.; Jan, S.; Khalid, M.; Ghous, T.; Akash, M.S.H. Pakistamide C, a new sphingolipid from Abutilon pakistanicum. Rev. Bras. Farmacogn. 2014, 24, 277-281. [CrossRef]

13. Baquar, S.R. Medicinal and poisonous plants of Pakistan. In Medicinal and Poisonous Plants of Pakistan; Printas: Karachi, Pakistan, 1989.

14. Mohamed, I.E.T.; Nur, E.; Abdelrahman, M.E.N. The antibacterial, antiviral activities and phytochemical screening of some Sudanese medicinal plants. EurAsian J. BioSciences 2010, 4. [CrossRef]

15. Gomaa, A.A.-R.; Samy, M.N.; Desoukey, S.Y.; Kamel, M.S. Phytochemistry and pharmacological activities of genus Abutilon: A review. J. Adv. Biomed. Pharm. Sci. 2018, 1, 56-74. [CrossRef]

16. Grochowski, D.M.; Uysal, S.; Aktumsek, A.; Granica, S.; Zengin, G.; Ceylan, R.; Locatelli, M.; Tomczyk, M. In vitro enzyme inhibitory properties, antioxidant activities, and phytochemical profile of Potentilla thuringiaca. Phytochem. Lett. 2017, 20,365-372. [CrossRef]

17. Mollica, A.; Zengin, G.; Locatelli, M.; Stefanucci, A.; Mocan, A.; Macedonio, G.; Carradori, S.; Onaolapo, O.; Onaolapo, A.; Adegoke, J. Anti-diabetic and anti-hyperlipidemic properties of Capparis spinosa L.: In vivo and in vitro evaluation of its nutraceutical potential. J. Funct. Foods 2017, 35, 32-42. [CrossRef]

18. Saleem, H.; Htar, T.T.; Naidu, R.; Nawawi, N.S.; Ahmad, I.; Ashraf, M.; Ahemad, N. Biological, chemical and toxicological perspectives on aerial and roots of Filago germanica (L.) huds: Functional approaches for novel phyto-pharmaceuticals. Food Chem. Toxicol. 2019, 123, 363-373. [CrossRef] [PubMed]

19. Irwin, J.J.; Sterling, T.; Mysinger, M.M.; Bolstad, E.S.; Coleman, R.G. ZINC: A free tool to discover chemistry for biology. J. Chem. Inf. Model. 2012, 52, 1757-1768. [CrossRef]

20. Pedretti, A.; Villa, L.; Vistoli, G. VEGA-an open platform to develop chemo-bio-informatics applications, using plug-in architecture and script programming. J. Comput. Aided Mol. Des. 2004, 18, 167-173. [CrossRef]

21. Sarker, S.D.; Latif, Z.; Gray, A.I. Natural product isolation: An overview. Methods Biotechnol. 2006, $20,36$.

22. Asghari, B.; Mafakheri, S.; Zarrabi, M.; Erdem, S.; Orhan, I.; Bahadori, M. Therapeutic target enzymes inhibitory potential, antioxidant activity, and rosmarinic acid content of Echium amoenum. S. Afr. J. Bot. 2018. [CrossRef]

23. Srividya, A.; Dhanabal, S.; Jeevitha, S.; Varthan, V.V.; Kumar, R.R. Relationship between antioxidant properties and chemical composition of Abutilon indicum Linn. Ind. J. Pharm. Sci. 2012, 74, 163. [CrossRef] [PubMed]

24. Sharma, A.; Sharma, R.; Singh, H. Phytochemical and pharmacological profile of Abutilon indicum L. Sweet: A review. Int. J. Pharm. Sci. Rev. Res. 2013, 20, 120-127. 
25. Kailasam, K.V. Abutilon indicum L. (Malvaceae)-Medicinal Potential Review. Pharmacogn. J. 2015, 7, $330-332$.

26. San Miguel-Chávez, R. Phenolic antioxidant capacity: A review of the state of the art. In Phenolic Compounds-Biological Activity; InTech Open: London, UK, 2017.

27. Loganayaki, N.; Siddhuraju, P.; Manian, S. Antioxidant activity and free radical scavenging capacity of phenolic extracts from Helicteres isora L. and Ceiba pentandra L. J. Food Sci. Technol. 2013, 50, 687-695. [CrossRef]

28. Sadeghi, Z.; Valizadeh, J.; Shermeh, O.A.; Akaberi, M. Antioxidant activity and total phenolic content of Boerhavia elegans (choisy) grown in Baluchestan, Iran. Avicenna J. Phytomed. 2015, 5, 1-9.

29. Kalogeropoulos, N.; Yanni, A.E.; Koutrotsios, G.; Aloupi, M. Bioactive microconstituents and antioxidant properties of wild edible mushrooms from the island of Lesvos, Greece. Food Chem. Toxicol. 2013, 55, 378-385. [CrossRef]

30. Sarikurkcu, C.; Ozer, M.S.; Tepe, B.; Dilek, E.; Ceylan, O. Phenolic composition, antioxidant and enzyme inhibitory activities of acetone, methanol and water extracts of Clinopodium vulgare L. subsp. vulgare L. Ind. Crops Prod. 2015, 76, 961-966. [CrossRef]

31. Marini, G.; Graikou, K.; Zengin, G.; Karikas, G.A.; Gupta, M.P.; Chinou, I. Phytochemical analysis and biological evaluation of three selected Cordia species from Panama. Ind. Crops Prod. 2018, 120, 84-89. [CrossRef]

32. Bahadori, M.B.; Dinparast, L.; Zengin, G.; Sarikurkcu, C.; Bahadori, S.; Asghari, B.; Movahhedin, N. Functional components, antidiabetic, anti-Alzheimer's disease, and antioxidant activities of Salvia syriaca L. Int. J. Food Prop. 2017, 20, 1761-1772. [CrossRef]

33. Zengin, G.; Sarikurkcu, C.; Uyar, P.; Aktumsek, A.; Uysal, S.; Kocak, M.S.; Ceylan, R. Crepis foetida L. subsp. rhoeadifolia (Bieb.) Celak. as a source of multifunctional agents: Cytotoxic and phytochemical evaluation. J. Funct. Foods 2015, 17, 698-708. [CrossRef]

34. Parveen, S.; Khalid, A.; Farooq, A.; Choudhary, M.I. Acetyl and butyrylcholinesterase-inhibiting triterpenoid alkaloids from Buxus papillosa. Phytochemistry 2001, 58, 963-968.

35. Yan, Y.-X.; Sun, Y.; Li, Z.-R.; Zhou, L.; Qiu, M.-H. Chemistry and biological activities of Buxus alkaloids. Curr. Bioact. Compd. 2011, 7, 47-64. [CrossRef]

36. Ingkaninan, K.; Temkitthawon, P.; Chuenchom, K.; Yuyaem, T.; Thongnoi, W. Screening for acetylcholinesterase inhibitory activity in plants used in Thai traditional rejuvenating and neurotonic remedies. J. Ethnopharmacol. 2003, 89, 261-264. [CrossRef]

37. Mukherjee, P.K.; Kumar, V.; Mal, M.; Houghton, P.J. Acetylcholinesterase inhibitors from plants. Phytomedicine 2007, 14, 289-300. [CrossRef] [PubMed]

38. Parmar, D.; Sachdeva, P.; Kukkar, M. Evaluation of protective role of Abutilon Indicum in Aluminium chloride induced Alzheimer's disease in Rats. J. Pharm. Sci. 2017, 7, 314-321.

39. Asghari, B.; Salehi, P.; Farimani, M.M.; Ebrahimi, S.N. $\alpha$-Glucosidase Inhibitors from Fruits of Rosa canina L. Rec. Nat. Prod. 2015, 9, 276-283.

40. Orhan, N.; Hoçbaç, S.; Orhan, D.D.; Asian, M.; Ergun, F. Enzyme inhibitory and radical scavenging effects of some antidiabetic plants of Turkey. Iran. J. Basic Med. Sci. 2014, 17, 426-432.

41. Picot, C.; Subratty, A.H.; Mahomoodally, M.F. Inhibitory potential of five traditionally used native antidiabetic medicinal plants on $\alpha$-amylase, $\alpha$-glucosidase, glucose entrapment, and amylolysis kinetics in vitro. Adv. Pharmacol. Sci. 2014, 2014. [CrossRef]

42. Saleem, F.; Sarkar, D.; Ankolekar, C.; Shetty, K. Phenolic bioactives and associated antioxidant and anti-hyperglycemic functions of select species of Apiaceae family targeting for type 2 diabetes relevant nutraceuticals. Ind. Crops Prod. 2017, 107, 518-525. [CrossRef]

43. Pant, G.; Sai, K.; Babasaheb, S.; Reddy, R.; Sibi, G. In vitro $\alpha$-amylase and $\alpha$-glucosidase inhibitor activity of abutilon indicum leaves. Asian J. Pharm. Clin. Res. 2013, 6, 22-24.

44. Neagu, E.; Roman, G.P.; Radu, G.L. Antioxidant capacity of some Symphytum officinalis extracts processed by ultrafiltration. Rom. Biotechnol. Lett. 2010, 15, 5505-5511.

45. Vujanović, M.; Zengin, G.; Đurović, S.; Mašković, P.; Cvetanović, A.; Radojković, M. Biological activity of extracts of traditional wild medicinal plants from the Balkan Peninsula. S. Afr. J. Bot. 2018. [CrossRef]

(C) 2020 by the authors. Licensee MDPI, Basel, Switzerland. This article is an open access article distributed under the terms and conditions of the Creative Commons Attribution (CC BY) license (http://creativecommons.org/licenses/by/4.0/). 